Article

\title{
Strategies for Waste Recycling: The Mechanical Performance of Concrete Based on Limestone and Plastic Waste
}

\author{
Marco Filippo Ferrotto ${ }^{1}\left(\mathbb{D}\right.$, Panagiotis G. Asteris ${ }^{2} \mathbb{D}$, Ruben Paul Borg ${ }^{3}\left(\mathbb{D}\right.$ and Liborio Cavaleri ${ }^{1, *}$ \\ 1 Department of Engineering, University of Palermo, Viale delle Scienze, 90128 Palermo, Italy; \\ marcofilippo.ferrotto@unipa.it \\ 2 Computational Mechanics Laboratory, School of Pedagogical and Technological Education, \\ 14121 Athens, Greece; panagiotisasteris@gmail.com \\ 3 Faculty for the Built Environment, University of Malta, MSD 2080 Msida, Malta; ruben.p.borg@um.edu.mt \\ * Correspondence: liborio.cavaleri@unipa.it
}

Citation: Ferrotto, M.F.; Asteris, P.G.; Borg, R.P.; Cavaleri, L. Strategies for Waste Recycling: The Mechanical Performance of Concrete Based on Limestone and Plastic Waste. Sustainability 2022, 14, 1706. https:// doi.org/10.3390/su14031706

Academic Editor: Syed Minhaj

Saleem Kazmi

Received: 13 December 2021

Accepted: 24 January 2022

Published: 1 February 2022

Publisher's Note: MDPI stays neutral with regard to jurisdictional claims in published maps and institutional affiliations.

Copyright: (C) 2022 by the authors. Licensee MDPI, Basel, Switzerland. This article is an open access article distributed under the terms and conditions of the Creative Commons Attribution (CC BY) license (https:// creativecommons.org/licenses/by/ $4.0 /)$.

\begin{abstract}
Recycling is among the best management strategies to avoid dispersion of several types of wastes in the environment. Research in recycling strategies is gaining increased importance in view of Circular Economy principles. The exploitation of waste, or byproducts, as alternative aggregate in concrete, results in a reduction in the exploitation of scarce natural resources. On the other hand, a productive use of waste leads to a reduction in the landfilling of waste material through the transformation of waste into a resource. In this frame of reference, the paper discusses how to use concrete as a container of waste focusing on the waste produced in limestone quarries and taking the challenge of introducing plastic waste into ordinary concrete mixes. To prove the possibility of reaching this objective with acceptable loss of performance, the mechanical characteristics of concrete mixed with additional alternative aggregates classified as waste are investigated and discussed in this paper through the presentation of two experimental campaigns. The first experimental investigation refers to concrete made with fine limestone waste used as a replacement for fine aggregate (sand), while the second experimental program refers to the inclusion of three types of plastic wastes in the concrete. Different mixes with different percentages of wastes are investigated to identify possible fields of application. The experimental results indicate that use of limestone quarry waste and use of plastic waste are possible within significant percentage ranges, having recognized a limited reduction of concrete strength that makes concrete itself appropriate for different practical applications.
\end{abstract}

Keywords: concrete; waste recycling; plastic; limestone; sustainability; mechanical performance

\section{Introduction}

Over the years the accumulation of waste has become a serious problem due to challenges in its disposal, and population growth, urbanization, industries, and trade in the world have significantly increased the production of waste. Global waste generation is increasing; recent studies report that the global production of resins and fibers increased from 2 million tons in 1950 to 380 million tons in 2015, and, if current production and waste management trends continue, around 12,000 million tons of plastic waste will end up in landfills or in the natural environment by 2050 [1]. Other studies estimate a current production rate of about 2 billion tons per year, and this number is projected to increase to 3.4 billion tons by 2050 [2]. This is obviously considered a topic of significance at the global scale because of the severe environmental consequences as well as the threat to human health.

Over the past few decades, different strategies for disposal and recycling of the wastes have been investigated. In most cases the focus is, first, how to reduce the volume of waste generated, and then, how to transform the waste into a resource [3-8].

Recycling is of the utmost importance in order to avoid the dispersion of waste into the environment, oceans, or its accumulation in landfills. However, nowadays, there is the need 
to identify innovative strategies, standardized methodologies, and funding mechanisms to recycle wastes. Recent studies suggest that, currently, about $19 \%$ of the total waste produced undergoes materials recovery through recycling and composting, and 11\% is treated through modern incineration. It is recognized that $33 \%$ of waste is openly dumped, and governments, whilst increasingly recognizing the risks and costs of dumpsites, are pursuing sustainable waste disposal methods [2].

Obviously, recycling strategies must be carefully planned according to the type of material to be recycled, considering all aspects related to environmental impacts, gas emissions, air pollution, etc.

The possibility of the wide exploitation of concrete as an effective instrument for waste disposal is discussed in this study. It is estimated that about 4-4.5 billion tons of cement are produced annually, while the production of concrete is about 30 billion tons, which corresponds to an annual worldwide demand of about 8-10 million tons of sand [9].

It is noted, however, that the production of concrete also presents negative impacts, particularly due to the use of cement which contributes to significant $\mathrm{CO}_{2}$ emissions and environmental pollution, the exploitation of non-renewable resources including aggregate, and its embodied energy.

The strategy for waste recycling as proposed in this research presents opportunities for lower exploitation of natural aggregate resources and recycling of waste materials.

The investigation refers to options for the recycling of different types of plastic waste, which would otherwise be destined for accumulation in landfills and contributing to environmental degradation. The investigation refers to the production of concrete intended to meet structural performance requirements [1-8].

Furthermore, a strategy to transform quarry waste into a resource is presented. In quarrying activities, rock is extracted and transformed into aggregates of various sizes for civil engineering applications. In this process, waste fine aggregate (dust waste) is generated. The disposal of this type of waste is expensive and is also a cause of environmental pollution (e.g., leaching into water reserves, atmospheric pollution because of small particles causing respiratory diseases or deposited on plants disrupting photosynthesis, affecting aquatic habitats, etc.). Several studies dealt with the use of quarry dust as fine aggregate for concrete as a strategy of recycling [10-19]. There is a growing interest in the waste generated and how the large volumes of waste can be transformed into an opportunity through recycling, because, as stated in several studies, [10-19], such a huge quantity of quarry waste may be considered as a resource of good quality. As reported in different published studies, the quarried limestone and marble waste can be used in engineering applications, such as road and railway construction as well as in the production of concrete. The waste sand, with the right characteristics, can also be exploited as a filler in self-compacting concrete applications [20].

In the case of limestone dust and plastic waste, a number of studies reported a reduction in mechanical concrete properties [10,13,17,21-23]. In the case of plastic waste recycling, a reduction of the bulk density can be obtained [21-23], proving advantageous in certain applications. The exploitation of PET fibers in concrete has also been assessed with respect to early age performance and crack behavior and also mechanical properties including compressive strength and flexural performance [24]. Another aspect that is focused on in the literature is the evaluation of durability, finding satisfactory results in the case of mixes with limestone dust [20-26], and a certain reduction in the overall performances in the case of mixes with plastics [27-29].

The objective is to explore recycling options and define the maximum quantities of these wastes that can be used in concrete mixes, retaining acceptable physical and mechanical characteristics and with the goal of reducing the accumulation of these waste streams. The shape and size of the aggregates, their physical characteristics, as well as their treatment prior to their addition to the concrete mix all play a fundamental role in the performance of the final product according to the objective investigations of other recent studies [30-34]. 
The paper discusses the role of waste, i.e., limestone waste sand and plastic, in concrete starting from the production process, the quantities involved and their exploitation as concrete mix constituents. In doing so, the major concerns are related to the mechanical performances and the durability of the concrete based on these types of wastes. These considerations are of the utmost importance in order to define the most suitable field of application of such waste-based concrete. On the basis of the investigation reported in this paper, fields of application are proposed with the ultimate objective of reducing the landfilling of large quantities of waste and transforming the latter into a resource.

The results of two experimental investigations are presented: the first one is carried out on concrete produced with fine limestone waste generated in the area of Trapani in Sicily as a by-product of quarrying activities. The limestone waste sand is exploited as a partial substitute of fine aggregate (sand). The second experimental investigation was carried out on concrete produced with plastic waste. For the latter, three different types of plastics were used separately, (i.e., each type of mix was produced with a different plastic), as follows: (i) plastic flakes, (ii) granulated plastic, and (iii) plastic sand.

The compressive strength results of the concrete produced with different percentages of waste aggregate were compared with the compressive strength of the control ordinary concrete in order to investigate variations in mechanical performance, depending on the percentage of recycled aggregate in the mix. Remarks on the potential applications of the concrete based on waste materials are presented at the end of the paper.

\section{Quarry Limestone Sand as Fine Aggregate for Concrete}

\subsection{Overview}

Several researchers investigated the advantages and disadvantages in using quarry waste sand as a partial or full substitute of the fine aggregate for concrete. The majority of studies were carried out through experimental investigations, observing the behavior of the concrete by varying the percentage of the quarry waste sand in the mix, from a low-tohigh percentage (up to $100 \%$ ) substitution of fine aggregate. The performance of concrete depends on the actual characteristics of the quarry waste. Most authors declare that the mechanical properties are affected by an increase in compressive strength of concrete mixed with low percentage substitution of quarry fine waste. For high percentage substitutions, i.e., from $30 \%$ to $60 \%$ replacement, the compressive strength of concrete is more or less comparable to that of concrete without quarry dust. For higher percentages (from $60 \%$ to full replacement) there is a reduction in the mechanical properties. This indicates that this material can be considered useful in structural applications and that the mechanical performance meets structural requirements as those for conventional concrete [10-19].

Some other studies refer to the use of quarry dust for the production of coarse aggregate through a cold bonding procedure [18].

In the present paper, attention is dedicated to the limestone of Custonaci, Sicily (locally the limestone is improperly referred to as a marble because it is worked as a marble). From available sources, it is known that it is a sedimentary rock constituted mainly by calcite $(98 \%)$ and $(2 \%)$ dolomite, apatite, illite, goethite, and quartz. It originated in a marine environment, after different processes of alteration, erosion, transport, and deposition of debris of pre-existing rocks and/or animal or plant remains. The physical-mechanical characteristics are as follows: unit volume weight $23-26 \mathrm{kN} / \mathrm{m}^{3}$, thermal expansion coefficient 0.0047-0.0043 $\mathrm{mm} / \mathrm{m}^{\circ} \mathrm{C}$, compressive strength 160-200 MPa, compressive strength after freeze/thaw 155-195 MPa, and tensile strength 13-17 MPa.

The experimental research and results from previous studies conducted by the authors are briefly described with the aim of providing an overview on the mechanical performance of concrete based on the replacement of fine aggregate (sand) with limestone waste sand.

\subsection{Experimental Investigation}

According to Cavaleri et al. [10], the experimental investigation was designed to have the fine aggregate of a reference control mix of ordinary concrete, progressively 
replaced with a single type of quarry waste sand, sourced from Custonaci (Sicily), with two percentages by weight referred to the amount of sand in the modified mix, $13 \%$ and $26 \%$, corresponding to $11 \%$ and $23 \%$ of the amount of sand in the reference mix. The reference concrete was produced using Portland limestone cement Type 32.5 as the hydraulic binding agent, together with quarried crushed fine aggregate with $2 \mathrm{~mm}$ nominal maximum size used as fine aggregate, and $20 \mathrm{~mm}$ crushed rock coarse aggregate. The target characteristic strength for the concrete without limestone waste sand (control mix) was $30 \mathrm{MPa}$. Each mix volume was set approximately at $1 / 21 \mathrm{of} \mathrm{a}^{3}$ in agreement to the characteristics of the mixer. Therefore, the reference mix was composed of $15 \mathrm{~kg}$ of cement, $38 \mathrm{~kg}$ of coarse aggregate, $35 \mathrm{~kg}$ of fine aggregate (sand) and a water/cement ratio of 0.5 . While, for the two modified mixes, the fine aggregate portion was composed of $31 \mathrm{~kg}$ of fine aggregate (sand) and $4 \mathrm{~kg}$ of quarry waste sand, and $27 \mathrm{~kg}$ of fine aggregate (sand) and $8 \mathrm{~kg}$ of quarry waste sand (Table 1).

Table 1. Mix design of the control concrete and the modified concretes.

\begin{tabular}{|c|c|c|c|}
\hline \multicolumn{4}{|c|}{$1 / 21$ of a Cubic $M$} \\
\hline & $\begin{array}{l}\text { Control Mix } \\
\text { Components } \\
{[\mathrm{kg}]}\end{array}$ & $\begin{array}{c}\text { Mix with } 13 \% \text { (of Ordinary } \\
\text { Sand) of Fine Quarry Waste } \\
{[\mathrm{kg}]}\end{array}$ & $\begin{array}{c}\text { Mix with } 26 \% \text { (of Ordinary Sand) } \\
\text { of Fine Quarry Waste [kg] }\end{array}$ \\
\hline Cement & 15 & 15 & 15 \\
\hline Water & 7.5 & 7.5 & 7.5 \\
\hline Fine Aggregate & 35 & 31 & 27 \\
\hline Quarried Waste Sand & 0 & 4 & 8 \\
\hline Coarse Aggregate & 38 & 38 & 38 \\
\hline $\begin{array}{l}\text { waste by weight percentage } \\
\text { introduction * }(\%)\end{array}$ & & 11 & 23 \\
\hline \multicolumn{4}{|c|}{1 Cubic M } \\
\hline Cement & 315 & 315 & 315 \\
\hline Water & 157 & 157 & 157 \\
\hline Fine Aggregate & 735 & 651 & 567 \\
\hline Quarried Waste Sand & 0 & 84 & 168 \\
\hline Coarse Aggregate & 798 & 798 & 798 \\
\hline
\end{tabular}

* Percentage calculated with respect to the amount of sand in the control mix.

The aggregate and cement were first mixed in a mixer and then the water was added to complete the mix. $150 \times 150 \times 150 \mathrm{~mm}$ specimens were cast in molds and compacted with a concrete vibrator. The specimens were demolded after $24 \mathrm{~h}$ and cured by immersion in water at $21^{\circ} \mathrm{C}$. Four specimens were prepared for testing at each testing age, and for each respective concrete mix: (i) control mix without quarry waste sand substitution; (ii) with $13 \%$ and (iii) $26 \%$ of quarry waste limestone sand (percentages calculated with respect to the fine aggregate in the modified mix). The compressive strength was determined at $3,7,14,28$, and 60 days respectively, with a total of 60 samples tested. Details about the concrete mixes are reported in Table 1. Figure 1 shows the variation of the strength at different ageing times of concrete and for different percentages of quarry waste limestone sand calculated, as mentioned before with respect to the fine aggregate in the modified mix (Table 1). Standard deviation is reported for each typology of tested specimens and is reported in Figure 1.

The cube concrete strength of the control mix (with no quarry waste limestone sand) at 28 days resulted in $38.3 \mathrm{MPa}$, while for the case of $13 \%$ and $26 \%$ of waste sand (percentages calculated with respect to the ordinary sand in the modified mix) the concrete strength was $41.74 \mathrm{MPa}$ and $36.57 \mathrm{MPa}$, respectively. The results indicated that the introduction of 
$13 \%$ waste sand and the reduction of the ordinary sand led to an increase in compressive strength, while the introduction of $23 \%$ waste sand and the reduction of the ordinary sand led to a decrease in strength, depending on the age of concrete. This performance was also confirmed in different literature sources [10-18]. The strength of the mix characterized by a of $23 \%$ waste sand at 60 days, however, is comparable to that of the control mix. Despite that the introduction of $23 \%$ of waste sand resulted in a decrease in the strength when compared to the control mix, the reduction in strength is less at 14 days than at 7 days and negligible at 60 days. Therefore, it can be noted that the material can be effectively used for the production of concrete, with improvements in mechanical characteristics if used in low substitution levels. Lower mechanical properties were reported when the waste is used in larger quantities. In the latter case, the loss in performance (with respect to strength only and without taking into account other performance criteria) is, however, such that it can be compensated for, with an increase in the cement content of the mix.
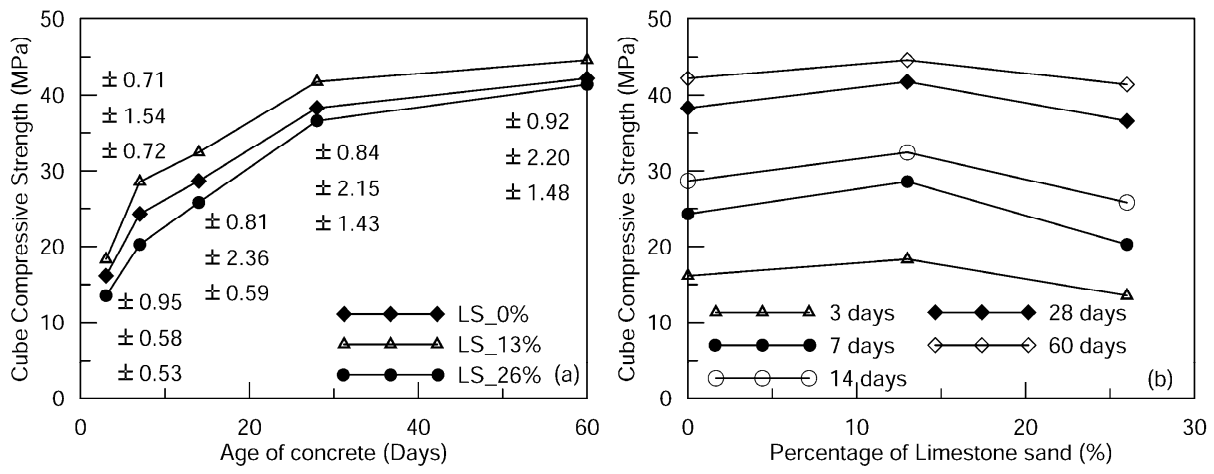

Figure 1. Concrete cube compressive strength: variation at different ages for given percentage of limestone sand (calculated with respect to the fine aggregates in the modified mix) (a); variation at different percentages of limestone sand (calculated with respect to the fine aggregates in the modified mix) at given age for the concrete (b). Average of four test results.

\section{Plastics Waste as Additional Aggregate for Concrete}

The potential for concrete produced with the addition or the substitution of part of the natural aggregate, with aggregate derived from plastic waste, has attracted the interest of the research community with the objective of reducing waste disposal and environmental pollution. Plastic wastes, mainly consisting of PE (polyethylene), PP (polypropylene), and PET (polyethylene terephthalate), are treated through a process of fusion, extrusion, and cutting of the molten paste, obtaining grains with different dimensions. Usually, these aggregates, included in the concrete mix design, result in a decrease in strength and lower density of concrete. Therefore, possible applications could be, in general, for non-structural use [1-8,21-23]. The use of the recycled plastics in concrete reduces the concrete bulk density by $2.5-13 \%$ for concrete containing plastic aggregates ranging from $10 \%$ to $50 \%$ of the volume of coarse aggregate. Although there are still gaps in research, the analysis of available research sources indicates that for Normal Strength Concrete (NSC), the compressive strength of concrete containing $10-50 \%$ recycled plastic aggregate drops to a percentage of around $40 \%$ with respect to that obtained with concrete without plastic. Consequently, the tensile strength is also affected by a significant reduction even in the case of a low percentage inclusion of plastics. At the same time, concrete containing plastic aggregates may exhibit more ductile behavior, when compared to concrete produced with conventional aggregates, even resulting in improved behavior in terms of reduction in crack formation and propagation.

It is reported that recycled plastic can be used in the repair and overlay of damaged, cement-based concrete surfaces in pavements, bridges, floors, and dams [22]. 


\subsection{Plastic Waste Typologies used as Additional Aggregate for Concrete}

The first type of plastic considered in the experimental program, discussed in the next paragraph, is in the form of plastic flakes, which are obtained by crushing and cutting different types of plastics (PET, PP, PVC) in order to have a material of irregular and variable shape and size, from medium to large dimensions (Figure 2a). This type of plastic was considered of interest because its preparation for mixing in concrete does not require any particular treatment, with respect to other types of plastics that require specific treatment, i.e., process of fusion, extrusion, and cutting or shredding. The bulk density of this type of plastic is $0.4 \mathrm{~kg} / \mathrm{lt}$.

The second type of plastic, that is, the granulated plastic, is obtained through a process of fusion, extrusion, and cutting of the molten paste, with the quasi-cylindrical grains obtained having a maximum size of around ten millimeters (Figure 2b). These types of plastics are PET, PE, and PP. The bulk density of this type of plastic is $0.58 \mathrm{~kg} / \mathrm{lt}$.

The third type of plastic, that is, the plastic sand, is obtained from the shredding of recycled plastics consisting mainly of PET, PP, and PVC (Figure 2c). It can contain impurities that derive from accidental intrusion during separate collections of particles, such as metals, wood, polyolefins, and residual contamination. However, these impurities consist of a very small portion. The bulk density of this type of plastic is $0.61 \mathrm{~kg} / \mathrm{lt}$.

These plastics were thoroughly cleaned and washed before they were fed into the machine which operates at a constant temperature and pressure. The palletized materials were collected from the output of the machine and allowed to cool. At the laboratory, the plastic samples were sieved to ensure that they fit the limiting particle size distribution requirements.

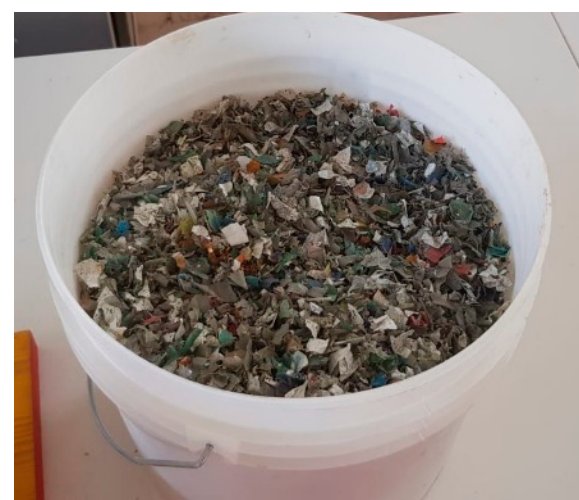

(a)

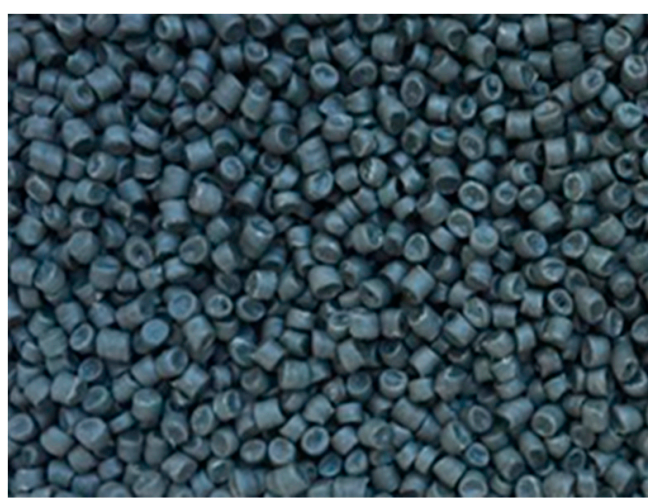

(b)

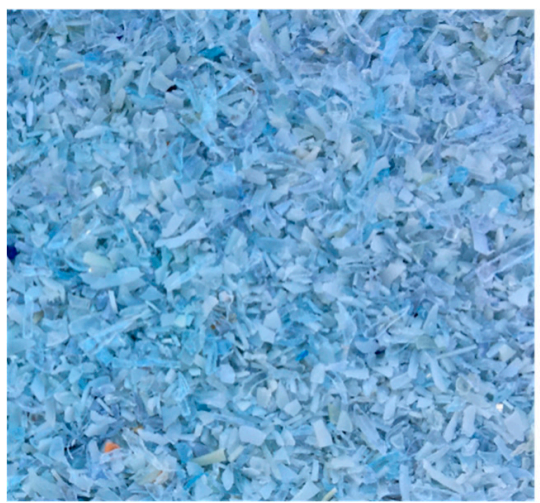

(c)

Figure 2. Random plastics flakes (a); granulated plastics (b); plastic sand (c).

\subsection{Experimental Investigation}

The experimental investigation included an ordinary concrete mix (control mix) where an additional volume percentage of plastic was added. The reference concrete was produced using Portland limestone cement Type 32.5 with quarry sand of $2 \mathrm{~mm}$ nominal maximum size used as fine aggregate, and $20 \mathrm{~mm}$ of crushed rock coarse aggregate.

As for the previous experimental program, the aggregate and cement were first mixed and then the water was added to complete the mix. $150 \times 150 \times 150 \mathrm{~mm}$ molds were used to cast the concrete that was compacted with a vibrator.

In the case of concrete mixed with plastic flakes, two different percentages of plastic were added to the control mix, that is $10 \%$ and $20 \%$ by volume. The control mix had a compressive strength of $18.45 \mathrm{MPa}$ at 28 days. For each mix, five tests were carried out at 7 , 14 , and 28 days, for a total of 45 specimens tested. Each mix volume was approximately $1 / 21$ of an $\mathrm{m}^{3}$. The reference mix was composed of $15.75 \mathrm{~kg}$ of cement, $36.75 \mathrm{~kg}$ of coarse aggregate, and $39.9 \mathrm{~kg}$ of sand. The water/cement ratio was 0.6 . The additional 
plastic flakes were $2 \mathrm{~kg}$ and $4 \mathrm{~kg}$ for the case of $10 \%$, and $20 \%$ of plastic addition by volume respectively.

For the case of granulated plastics, two mixes were prepared with the same target compressive strength. The two control mixes (with no additional plastics) provided around $39.5 \mathrm{MPa}$ at 28 days. Regarding the specimens mixed with plastics, two different percentage of the volume of the control mix were used for the first mix, that were $12.5 \%$ and $25 \%$, and 3 different percentage were used for the second mix, which were $10 \%, 20 \%$ and $30 \%$. For each mix, three samples were cast for each ageing time and tests were carried out at 7, 14, and 28 days, for a total of 63 specimen tested. The two reference mixes were composed of $2.45 \mathrm{~kg}$ of cement, $3.34 \mathrm{~kg}$ of sand, $6.45 \mathrm{~kg}$ of coarse aggregate, and a water/cement ratio of 0.5 . The additional granulated plastic consisted in $0.375 \mathrm{~kg}$ and $0.75 \mathrm{~kg}$ for the case of $12.5 \%$ and $25 \%$ respectively, and $0.3 \mathrm{~kg}, 0.64 \mathrm{~kg}$ and $0.96 \mathrm{~kg}$ for the case of $10 \%, 20 \%$ and $30 \%$ respectively.

For the case of plastic sand, two control mixes were prepared with a compressive strength at 28 days of $22.6 \mathrm{MPa}$ and $39.5 \mathrm{MPa}$, respectively. Regarding the specimens mixed with plastics, 3 different percentage of the volume of the control mix were used for the first mix, which were $10 \%, 20 \%$, and $30 \%$, and 4 different percentages were used for the second mix, which were $2 \%, 4 \%, 6 \%$, and $30 \%$. For each mix, 3 samples were cast for each ageing time and tests were carried out at 7,14, and 28 days, for a total of 81 specimens tested. The first reference mix was composed of $1.75 \mathrm{~kg}$ of cement, $3.71 \mathrm{~kg}$ of sand, $6.45 \mathrm{~kg}$ of coarse aggregate, and a water/cement ratio of 0.5 , while the second reference mix was composed of $2.45 \mathrm{~kg}$ of cement, $3.71 \mathrm{~kg}$ of sand, $6.45 \mathrm{~kg}$ of coarse aggregate and a water/cement ratio of 0.5 . The additional powder plastics were $0.371 \mathrm{~kg}, 0.742 \mathrm{~kg}$, and $1.113 \mathrm{~kg}$ for the case of $10 \%, 20 \%$, and $30 \%$, respectively, for the first mix, while $0.075 \mathrm{~kg}, 0.150 \mathrm{~kg}, 0.222 \mathrm{~kg}$, and $1.113 \mathrm{~kg}$ for the case of $2 \%, 4 \%, 6 \%$, and $30 \%$, respectively, for the second mix.

Details about the concrete mixes are reported in Tables $2-5$ including the amounts in 1 cube $\mathrm{m}$ of concrete.

Figures 3 and 4 show pictures of the concrete casting and the specimen at failure for the different mixes.

Table 2. Flake plastic-Mix design of the control concrete and the modified concretes.

\begin{tabular}{|c|c|c|c|}
\hline \multicolumn{4}{|c|}{$1 / 21$ of a Cubic $M+$ Waste } \\
\hline & $\begin{array}{l}\text { Control Mix } \\
\text { Comp. [kg] }\end{array}$ & $\begin{array}{l}\text { Mix with } 10 \% \text { Waste by } \\
\text { Volume }[\mathrm{kg}]\end{array}$ & $\begin{array}{l}\text { Mix with } 20 \% \text { Waste by } \\
\text { Volume [kg] }\end{array}$ \\
\hline Cement & 15.75 & 15.75 & 15.75 \\
\hline Water & 9.45 & 9.45 & 9.45 \\
\hline Fine Aggregate & 39.9 & 39.9 & 39.9 \\
\hline Flake plastic & 0 & 2 & 4 \\
\hline Coarse Aggregate & 36.75 & 36.75 & 36.75 \\
\hline $\begin{array}{l}\text { By volume Percentage of flake } \\
\text { plastic }(\%)\end{array}$ & & 10 & 20 \\
\hline \multicolumn{4}{|c|}{1 Cubic $M+$ Waste } \\
\hline Cement & 330.7 & 330.7 & 330.7 \\
\hline Water & 198.5 & 198.5 & 198.5 \\
\hline Fine Aggregate & 837.9 & 837.9 & 837.9 \\
\hline Flake plastic & 0 & 42 & 84 \\
\hline Coarse Aggregate & 771.7 & 771.7 & 771.7 \\
\hline
\end{tabular}


Table 3. Granulated plastic-Mix design of the control concrete and the modified concretes.

\begin{tabular}{|c|c|c|c|c|c|c|}
\hline \multicolumn{7}{|c|}{ 5.67/1000 of a Cubic M + Waste } \\
\hline & $\begin{array}{l}\text { Control } \\
\text { Mix } \\
\text { Comp. [kg] }\end{array}$ & $\begin{array}{c}\text { Mix with } 10 \% \\
\text { by Volume } \\
\text { [kg] }\end{array}$ & $\begin{array}{c}\text { Mix with } 20 \% \\
\text { by Volume } \\
{[\mathrm{kg}]}\end{array}$ & $\begin{array}{c}\text { Mix with } 30 \% \\
\text { by Volume } \\
{[\mathrm{kg}]}\end{array}$ & $\begin{array}{c}\text { Mix with } 12.5 \% \\
\text { by Volume } \\
{[\mathrm{kg}]}\end{array}$ & $\begin{array}{c}\text { Mix with } 25 \% \\
\text { by Volume } \\
{[\mathrm{kg}]}\end{array}$ \\
\hline Cement & 2.45 & 2.45 & 2.45 & 2.45 & 2.45 & 2.45 \\
\hline Water & 1.22 & 1.22 & 1.22 & 1.22 & 1.22 & 1.22 \\
\hline Fine Aggregate & 3.34 & 3.34 & 3.34 & 3.34 & 3.34 & 3.34 \\
\hline Granulated plastic & 0 & 0.3 & 0.64 & 0.96 & 0.375 & 0.75 \\
\hline Coarse Aggregate & 6.45 & 6.45 & 6.45 & 6.45 & 6.45 & 6.45 \\
\hline $\begin{array}{l}\text { By volume Percentage of } \\
\text { granulated plastic }(\%)\end{array}$ & & 10 & 20 & 30 & 12.5 & 25 \\
\hline \multicolumn{7}{|c|}{1 Cubic $M+$ Waste } \\
\hline Cement & 430 & 430 & 430 & 430 & 430 & 430 \\
\hline Water & 215 & 215 & 215 & 215 & 215 & 215 \\
\hline Fine Aggregate & 589 & 589 & 589 & 589 & 589 & 589 \\
\hline Granulated plastic & 0 & 52.9 & 112.9 & 169 & 66.1 & 132.3 \\
\hline Coarse Aggregate & 1137 & 1137 & 1137 & 1137 & 1137 & 1137 \\
\hline
\end{tabular}

Table 4. Sand plastic-Mix design of the control concrete and the modified concretes (mix 1).

\begin{tabular}{|c|c|c|c|c|}
\hline \multicolumn{5}{|c|}{$5.67 / 1000$ of a Cubic M } \\
\hline & $\begin{array}{c}\text { Control Mix } \\
\text { Comp. } \\
{[\mathrm{kg}]}\end{array}$ & $\begin{array}{c}\text { Mix with } 10 \% \\
\text { by Volume } \\
{[\mathrm{kg}]}\end{array}$ & $\begin{array}{c}\text { Mix with } 20 \% \\
\text { by Volume } \\
\text { [kg] }\end{array}$ & $\begin{array}{c}\text { Mix with } 30 \% \\
\text { by Volume } \\
{[\mathrm{kg}]}\end{array}$ \\
\hline Cement & 1.75 & 1.75 & 1.75 & 1.75 \\
\hline Water & 0.87 & 0.87 & 0.87 & 0.87 \\
\hline Fine Aggregate & 3.71 & 3.71 & 3.71 & 3.71 \\
\hline Sand plastic & 0 & 0.371 & 0.742 & 1.113 \\
\hline Coarse Aggregate & 6.45 & 6.45 & 6.45 & 6.45 \\
\hline $\begin{array}{l}\text { By volume Percentage of sand } \\
\text { plastic }(\%)\end{array}$ & & 10 & 20 & 30 \\
\hline \multicolumn{5}{|c|}{1 Cubic M } \\
\hline Cement & 308 & 308 & 308 & 308 \\
\hline Water & 153 & 153 & 153 & 153 \\
\hline Fine Aggregate & 654 & 654 & 654 & 654 \\
\hline Sand plastic & 0 & 65 & 130 & 195 \\
\hline Coarse Aggregate & 1137 & 1137 & 1137 & 1137 \\
\hline
\end{tabular}


Table 5. Sand plastic-Mix design of the control concrete and the modified concretes (mix 2).

\begin{tabular}{|c|c|c|c|c|c|}
\hline \multicolumn{6}{|c|}{$5.67 / 1000$ of a Cubic M } \\
\hline & $\begin{array}{c}\text { Control Mix } \\
\text { Comp. } \\
{[\mathrm{kg}]}\end{array}$ & $\begin{array}{c}\text { Mix with } 2 \% \\
\text { by Volume } \\
{[\mathrm{kg}]}\end{array}$ & $\begin{array}{c}\text { Mix with } 4 \% \\
\text { by Volume } \\
{[\mathrm{kg}]}\end{array}$ & $\begin{array}{c}\text { Mix with } 6 \% \\
\text { by Volume } \\
{[\mathrm{kg}]}\end{array}$ & $\begin{array}{c}\text { Mix with } 30 \% \\
\text { by Volume } \\
{[\mathrm{kg}]}\end{array}$ \\
\hline Cement & 2.45 & 2.45 & 2.45 & 2.45 & 2.45 \\
\hline Water & 1.22 & 1.22 & 1.22 & 1.22 & 1.22 \\
\hline Fine Aggregate & 3.71 & 3.71 & 3.71 & 3.71 & 3.71 \\
\hline Sand plastic & 0 & 0.075 & 0.150 & 0.222 & 1.113 \\
\hline Coarse Aggregate & 6.45 & 6.45 & 6.45 & 6.45 & 6.45 \\
\hline $\begin{array}{c}\text { By volume Percentage of } \\
\text { sand plastic }(\%)\end{array}$ & & 2 & 4 & 6 & 30 \\
\hline \multicolumn{6}{|c|}{1 Cubic M } \\
\hline Cement & 308 & 308 & 308 & 308 & 308 \\
\hline Water & 153 & 153 & 153 & 153 & 153 \\
\hline Fine Aggregate & 654 & 654 & 654 & 654 & 654 \\
\hline Sand plastic & 0 & 13.22 & 26.40 & 39.7 & 195 \\
\hline Coarse Aggregate & 1137 & 1137 & 1137 & 1137 & 1137 \\
\hline
\end{tabular}

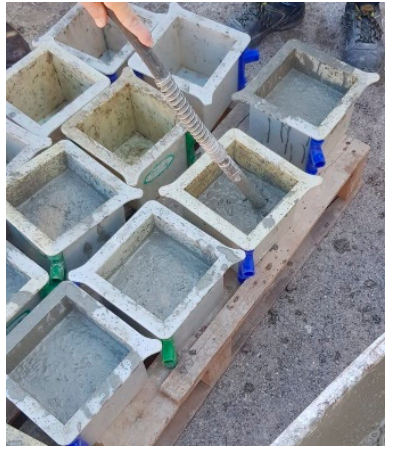

(a)

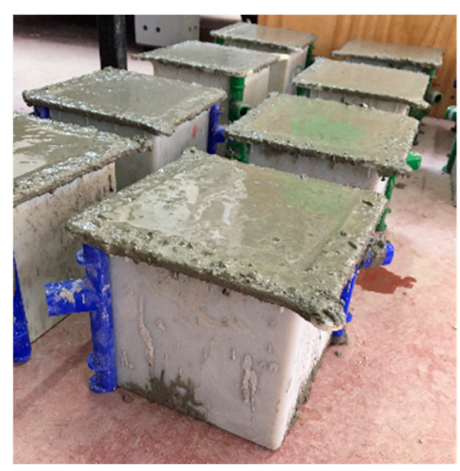

(b)

Figure 3. Concrete casting. Vibration of the concrete (a); Concrete cubes (b).

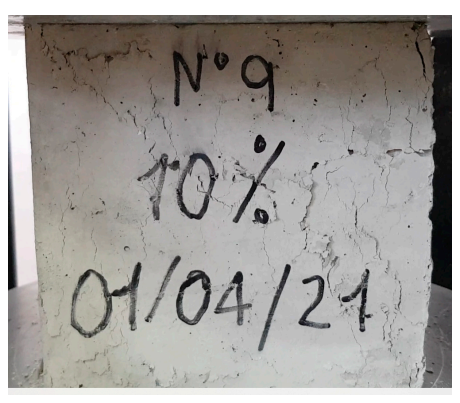

(a)

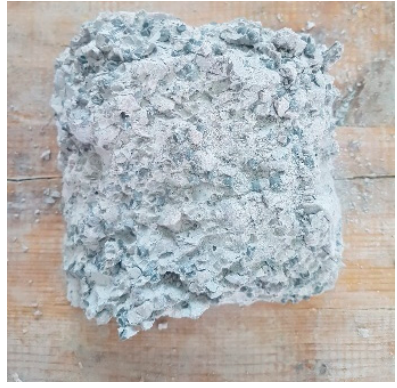

(b)

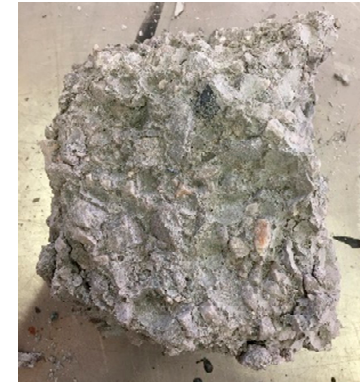

(c)

Figure 4. Specimen at failure: concrete with plastic flakes (a); concrete with granulated plastics (b); concrete with plastic sand (c).

Figures 5-7 show the variation of the strength at different ageing times of concrete and for different percentages of plastics. In the legend, "PET-R" indicates plastic flakes, "PET-G" indicates granulated plastics, and "PET-P" indicates plastic sand. Standard deviation is reported for each typology of tested specimens. 
The results indicated that for all the specimens, the relative strength improved, with a strength gain from the tests carried out at 7 days to those carried out at 28 days. Further, the ratio between the increment of strength achieved and increment of curing days was, in general, similar for all the tested specimens (both for the control mixes and for the mixes produced with plastics). It is also confirmed that the compressive strength decreases with the increase in the content of plastic in concrete. In detail, in the case of plastic flakes, the ratio of the strengths between the concrete with $10 \%$ and $20 \%$ of plastics and the ordinary concrete was 0.79 and 0.5 at 7 days, 0.72 and 0.49 at 14 days, and 0.7 and 0.46 at 28 days, indicating that the concrete underwent a strength reduction of $30 \%$ and $54 \%$ for the cases of $10 \%$ and $20 \%$ of plastics, respectively.

Similar considerations can be made for the specimen with the other types of plastics. In the case of granulated plastics, the ratio of the strength between the concrete with 10\%, $12.5 \%, 20 \%, 25 \%$, and $30 \%$ of plastics and the ordinary concrete was $0.72,0.75,0.61,0.53$, and 0.36 at 7 days, $0.78,0.77,0.65,0.53$, and 0.38 at 14 days, and $0.8,0.79,0.66,0.54$, and 0.38 at 28 days, indicating that the concrete underwent a strength reduction of $20 \%, 21 \%, 44 \%, 56 \%$, and $72 \%$ for the cases of $10 \%, 12.5 \%, 20 \%, 25 \%$, and $30 \%$ of additional plastics, respectively.

Finally, in the case of powder plastics, the ratio of the strengths between the concrete with $2 \%, 4 \%, 6 \%, 10 \%, 20 \%$, and $30 \%$ of plastic and the ordinary concrete, was $0.88,0.86$, $0.79,0.83,0.65$, and 0.5 at 7 days, $0.91,0.84,0.79,0.82,0.65$, and 0.52 at 14 days, and 0.91 , $0.84,0.79,0.82,0.65$, and 0.0 .51 at 28 days. In this case, some difference is observed for the two mixes (PET-P1 and PET-P2) because the strength reduction in the case of $6 \%$ plastic resulted as higher than that of $10 \%$ plastic. On the other hand, it must be stated that these two mixes had two different strengths, that is, 22.6 MPa for the first mix and $39.7 \mathrm{MPa}$ for the second mix. This result gives some information about the role of the compressive strength of the concrete; it seems that the higher the compressive strength, the higher the strength reduction when the plastics are added to the mix. Verification can be obtained through additional investigation.
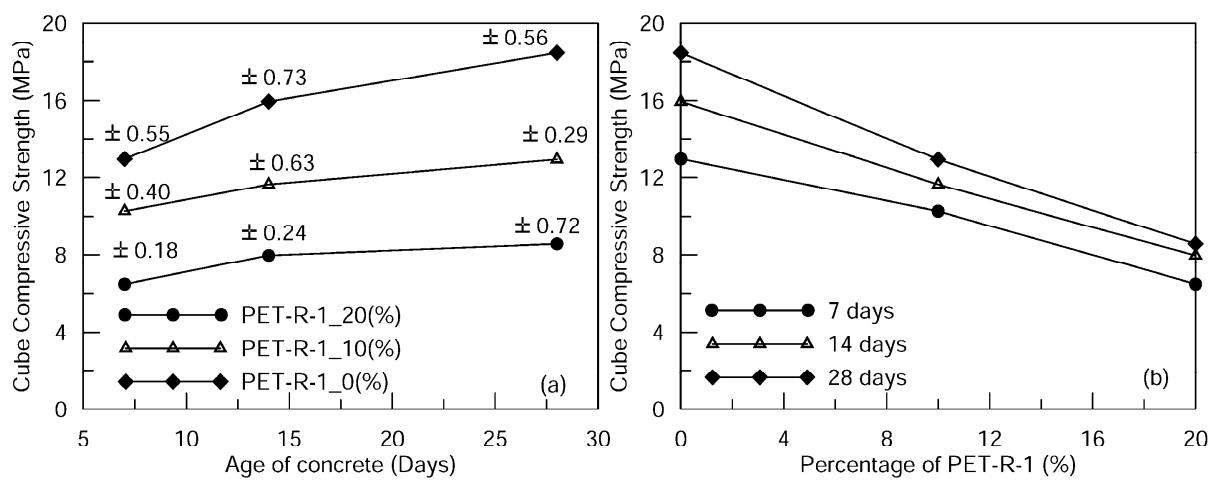

Figure 5. Concrete cube compressive strength: variation at different curing days for given percentage of plastic flakes (a) and variation at different percentages at a given concrete curing time (b). Average of three test results. 

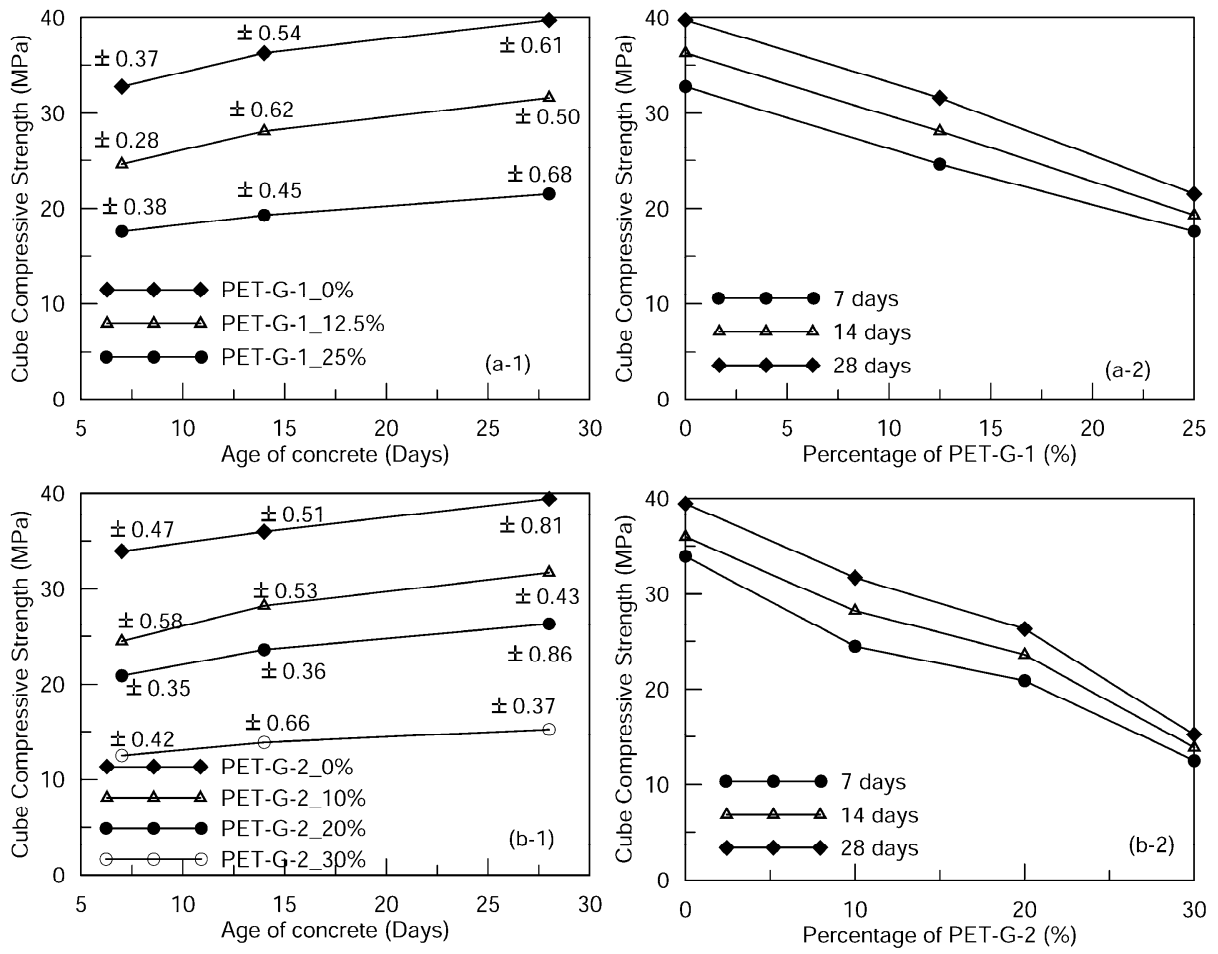

Figure 6. Concrete cube compressive strength: variation at different curing days for given percentage of granulated plastics (a-1, $\mathbf{b}-\mathbf{1})$ and variation at different percentages at a given concrete curing time $(\mathbf{a}-\mathbf{2}, \mathbf{b}-2)$. Average of three test results.
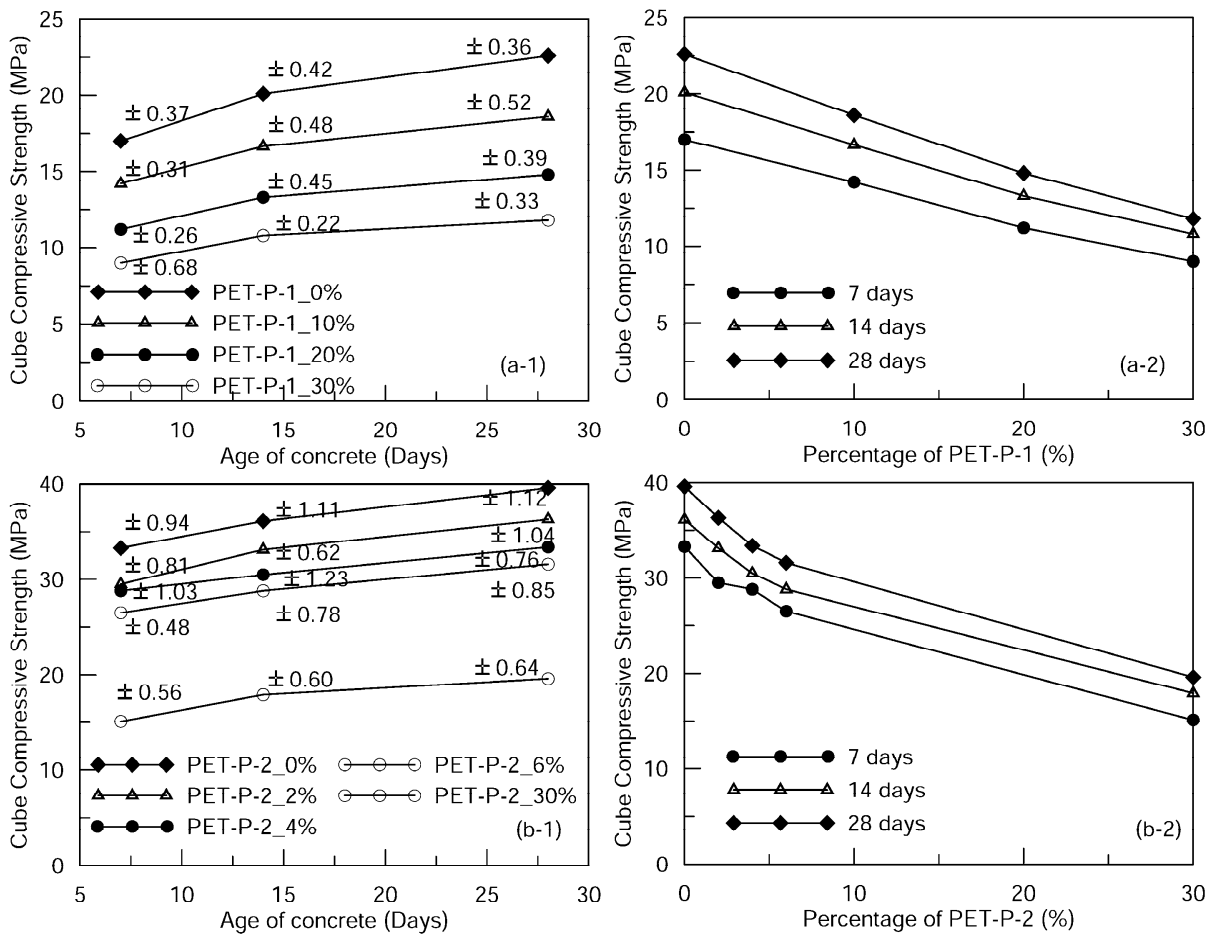

Figure 7. Concrete cube compressive strength: variation at different curing days for a given percentage of plastic sand $(\mathbf{a}-\mathbf{1}, \mathbf{b}-\mathbf{1})$ and variation at different percentages at aiven concrete curing time $(\mathbf{a}-\mathbf{2}, \mathbf{b}-2)$. Average of three test results. 


\section{Performance Comparisons and Discussion}

The overall performance of the tested specimen for all the mixes with different aggregates, that is, quarry limestone waste sand, plastic flakes, granulated plastics, and plastic sand, is analyzed. The analysis is based on normalized strength with respect to the strength obtained for the control mix of ordinary concrete (with no waste as aggregates). Percentages of each material used in the mix are shown in Table 6. After a comparison of the cement normalized mixes, and of the 28 days strength, in Figure 8, the normalized concrete strength is shown, with reference to the percentage replacement of waste aggregate (in the case of quarry waste limestone sand) or addition of waste aggregate (as in the case of waste plastic) indicating the percentage strength reduction at 28 days. It is possible to note that, in the case of quarry waste limestone, as stated in the previous section, there is no significant reduction in strength for the maximum percentage of sand waste introduction considered in this study ( $26 \%$ of the ordinary sand in the modified mix). At the same time, in the case of concrete with plastics, the reduction in strength is evident for a high percentage of additional plastics. This reduction is critical for percentages of plastics from $20 \%$ of the original mix volume upwards. The strong reduction of strength, obtained in the case of plastic waste high percentage, agrees with the results obtained by Visweswara et al. [28] and Hameed and Ahmed [20]. However, in the first case the reduction is very much higher, while in the second case the strength reduction is lower than that obtained during the experimental campaign here described. Further, in the first case of the strength of the control mix is around $50 \mathrm{MPa}$, therefore much higher than the control mix strength in the present experimental campaign. While, in the second case, even though the strength of the control mix is similar, the mix with plastic waste does not contain coarse aggregate different from the case here studied.

Table 6. Comparative mixes and strengths.

\begin{tabular}{|c|c|c|c|c|c|c|c|}
\hline $\begin{array}{l}\text { Cement } \\
\text { (Weight) }\end{array}$ & $\begin{array}{c}\text { Water } \\
\text { (Weight) }\end{array}$ & $\begin{array}{c}\text { Sand } \\
\text { (Weight) }\end{array}$ & $\begin{array}{l}\text { Aggregate } \\
\text { (Weight) }\end{array}$ & $\begin{array}{c}\text { Waste } \\
\text { Aggregate } \\
\text { (Weight) }\end{array}$ & $\begin{array}{c}\text { Type of } \\
\text { Waste } \\
\text { Aggregate }\end{array}$ & $\begin{array}{c}\text { By Volume } \\
\text { Percentage of } \\
\text { Additional } \\
\text { Waste }\end{array}$ & $\begin{array}{l}\text { Strength at } \\
28 \text { Days } \\
\text { (MPa) }\end{array}$ \\
\hline 1.00 & 0.5 & $\begin{array}{l}2.33 \\
2.07 \\
1.80\end{array}$ & $\begin{array}{l}2.53 \\
2.53 \\
2.53\end{array}$ & $\begin{array}{c}0.00 \\
0.26 \\
0.5\end{array}$ & $\begin{array}{l}\text { Limestone } \\
\text { sand }\end{array}$ & $\begin{array}{l}* \\
* \\
*\end{array}$ & $\begin{array}{c}38.3 \\
41.74 \\
36.57\end{array}$ \\
\hline 1.00 & 0.5 & $\begin{array}{l}1.363 \\
1.363 \\
1.363\end{array}$ & $\begin{array}{l}2.622 \\
2.622 \\
2.622\end{array}$ & $\begin{array}{c}0.00 \\
0.153 \\
0.306\end{array}$ & $\begin{array}{c}\text { Granulated } \\
\text { (PET-G1) }\end{array}$ & $\begin{array}{c}0 \\
12.5 \\
25\end{array}$ & $\begin{array}{c}39.73 \\
31.6 \\
21.5\end{array}$ \\
\hline 1.00 & 0.5 & $\begin{array}{l}1.514 \\
1.514 \\
1.514 \\
1.514\end{array}$ & $\begin{array}{l}2.622 \\
2.622 \\
2.622 \\
2.622\end{array}$ & $\begin{array}{c}0.00 \\
0.163 \\
0.327 \\
0.490\end{array}$ & $\begin{array}{c}\text { Granulated } \\
\text { (PET-G2) }\end{array}$ & $\begin{array}{c}0 \\
10 \\
20 \\
30\end{array}$ & $\begin{array}{l}39.42 \\
31.72 \\
26.28 \\
15.23\end{array}$ \\
\hline 1.00 & 0.5 & $\begin{array}{l}2.120 \\
2.120 \\
2.120 \\
2.120\end{array}$ & $\begin{array}{l}3.671 \\
3.671 \\
3.671 \\
3.671\end{array}$ & $\begin{array}{l}0.000 \\
0.212 \\
0.424 \\
0.636\end{array}$ & $\begin{array}{l}\text { Powder } \\
\text { (PET-P1) }\end{array}$ & $\begin{array}{c}0 \\
10 \\
20 \\
30\end{array}$ & $\begin{array}{l}22.6 \\
18.6 \\
14.8 \\
11.8\end{array}$ \\
\hline 1.00 & 0.5 & $\begin{array}{l}1.51 \\
1.51 \\
1.51 \\
1.51 \\
1.51\end{array}$ & $\begin{array}{l}2.62 \\
2.62 \\
2.62 \\
2.62 \\
2.62\end{array}$ & $\begin{array}{l}0.00 \\
0.05 \\
0.10 \\
0.15 \\
0.64\end{array}$ & $\begin{array}{l}\text { Powder } \\
\text { (PET-P2) }\end{array}$ & $\begin{array}{c}0 \\
2 \\
4 \\
6 \\
30\end{array}$ & $\begin{array}{l}39.5 \\
36.3 \\
33.4 \\
31.6 \\
19.6\end{array}$ \\
\hline 1.00 & 0.5 & $\begin{array}{l}2.53 \\
2.53 \\
2.53\end{array}$ & $\begin{array}{l}2.33 \\
2.33 \\
2.33\end{array}$ & $\begin{array}{l}0.00 \\
0.13 \\
0.25\end{array}$ & $\begin{array}{c}\text { Flake } \\
\text { (PET-R) }\end{array}$ & $\begin{array}{c}0 \\
10 \\
20\end{array}$ & $\begin{array}{c}18.452 \\
12.924 \\
8.572\end{array}$ \\
\hline
\end{tabular}

* datum not included. 


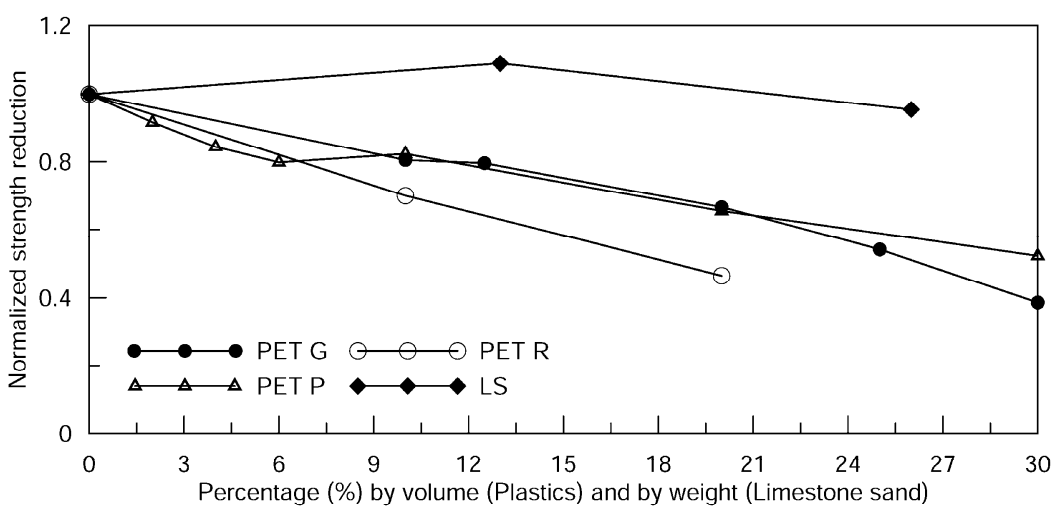

Figure 8. Normalized concrete strength reduction for different type of additional other aggregates.

No other experimental campaigns in the literature are so similar to allow a reasonable comparison.

While in the case of quarry waste limestone sand it can be said that the concrete can be still considered adequate for use in structural application for load-bearing elements, in the case of concrete with plastics, it is important to define suitable fields of application, depending on the actual mechanical characteristics, as affected by a reduction in performance. Possible fields of application of the waste plastic-based concrete, according also to various studies [21-23], include:

- $\quad$ Road pavements vibrated by power-operated machines.

- $\quad$ Road pavements vibrated by hand-operated machines.

- Mass foundations or lightly reinforced sections with vibrations.

- Repair and overlay of damaged, cement-based concrete surfaces in pavements, bridges, floors, and dams.

Other aspects, as for the durability of these types of concrete mixes, are of importance in view of the design of adequate use in practice and will be the next step of the research.

\section{Conclusions}

The paper presented the results of an experimental campaign carried out on concrete mixed with waste materials as replacement and additional aggregate. Quarry limestone dust was used as a partial replacement of sand in the concrete mix, while plastics (flakes, granulated and in the form of sand) were used as additional aggregate, as a percentage of the original mix volume. Based on the results, it was found that:

- In the case of quarry waste limestone sand used as partial replacement of the sand, and having the characteristic of a filler, if used in low quantities can lead to improvements in the mechanical characteristics of concrete. On the other hand, lower mechanical properties were reported when the quarry waste limestone sand is used in larger quantities. In the latter case, the loss in performance is such that it can be compensated for, with an increase in the cement content in the mix.

- In the case of concrete with plastic, for all the types of plastics analyzed, a reduction of the strength of concrete was reported, with higher reduction in strength with increasing percentage plastic content in the mix. This reduction is significant for low percentages of plastics and can halve the strength of the concrete for high amounts of plastics (around $30 \%$ of the original mixed volume of ordinary concrete). However, important information is obtained regarding the performance of plastic-based concrete; this information enables the exploitation of this waste in specific fields of application, satisfying particular performance requirements.

The results can be considered of interest and provide a base study for further research on the mechanical performances and durability of concrete based on quarry limestone waste sand and different types of plastics, as applied in specific fields. For example, 
given an optimal mix in the case of quarry waste limestone sand, the concrete can still be used for load-bearing elements in structures, while in the case of concrete with plastics, applications can include concrete screeds, lean foundations, or massive concrete casts, where the strength of the concrete plays a secondary role (however with the possibility to limit, by a preliminary assessment, to one third the amount of plastics in the sea only by treating $5 \%$ of the concrete production in the world). However, the investigation confirmed the potential of different waste streams as a source of aggregate for concrete and the effectiveness of recycling of waste and industrial byproducts, as an alternative to waste disposal.

Author Contributions: Conceptualization, resources: L.C. and P.G.A.; methodology: L.C., M.F.F. and P.G.A.; writing-review and editing: M.F.F. and R.P.B. All authors have read and agreed to the published version of the manuscript.

Funding: This research received no external funding.

Institutional Review Board Statement: Not applicable.

Informed Consent Statement: Not applicable.

Data Availability Statement: The data presented in this study are available on request from the corresponding author.

Conflicts of Interest: The authors declare no conflict of interest.

\section{References}

1. Geyer, R.; Jambeck, J.R.; Law, K.L. Production, use, and fate of all plastics ever made. Sci. Adv. 2017, 3, e1700782. [CrossRef] [PubMed]

2. Kaza, S.; Yao, L.C.; Bhada-Tata, P.; Van Woerden, F. What a Waste 2.0: A Global Snapshot of Solid Waste Management to 2050; Urban Development; World Bank: Washington, DC, USA, 2018; (C) World Bank. License: CC BY 3.0 IGO. Available online: https:/ / openknowledge.worldbank.org/handle/10986/30317 (accessed on 12 October 2021).

3. Kazemi, M.; Kabir, S.F.; Fini, E.H. State of the art in recycling waste thermoplastics and thermosets and their applications in construction. Resour. Conserv. Recycl. 2021, 174, 105776. [CrossRef]

4. Venkatesh, N. Plastic Mix Concrete by Using Waste Plastic Powder and Plastic Granules with Workability Test. Int. J. Multidiscip. Res. Mod. Edu. 2017, 3, 23-27.

5. Akinyele, J.O.; Ajede, A. The use of granulated plastic waste in structural concrete. Afr. J. Sci. Tech. Innov. Dev. 2018, 10, 169-175. [CrossRef]

6. Qureshi, M.S.; Oasmaa, A.; Pihkola, H.; Deviatkin, I.; Tenhunen, A.; Mannila, J.; Minkkinen, H.; Pohjakallio, M.; Laine-Ylijoki, J. Pyrolysis of plastic waste: Opportunities and challenges. J. Anal. Appl. Pyrolysis 2020, 152, 104804. [CrossRef]

7. Thiounn, T.; Smith, R.C. Advances and approaches for chemical recycling of plastic waste. J. Polym. Sci. 2020, 58, 1347-1364. [CrossRef]

8. Di, J.; Reck, B.K.; Miatto, A.; Graedel, T.E. United States plastics: Large flows, short lifetimes, and negligible recycling. Res. Conservat. Recycl. 2021, 167, 105440. [CrossRef]

9. Federbeton Confindustria. Rapporto di Filiera 2019. 2020. Available online: https:/ /www.federbeton.it/ (accessed on 5 October 2021).

10. Cavaleri, L.; Borg, R.P.; La Mantia, F.P.; Liguori, V. Quarry limestone dust as fine aggregate for concrete. In Proceedings of the IOP Conference Series: Materials Science and Engineering, FIB Conference: Sustainable Concrete: Materials and Structures, Valletta, Malta, 10 April 2018; Institute of Physics Publishing (IOP): Bristol, UK, 2018; Volume 442, p. 012003. Available online: https:/ /iopscience.iop.org/article/10.1088/1757-899X/442/1/012003 (accessed on 10 October 2021).

11. Bahoria, B.V.; Parbat, D.K.; Nagarnaik, P.B.; Waghe, U.P. Effect of characterization properties on compressive strength of concrete containing quarry dust and waste plastic as fine aggregate. Int. J. Civ. Eng. Tech. (IJCIET) 2017, 8, 699-707.

12. Rai, B.; Kumar, S.; Satish, K. Effect of Quarry Waste on Self-Compacting Concrete Containing Binary Cementitious Blends of Fly Ash and Cement. Adv. Mater. Sci. Eng. 2016, 2016, 1326960. [CrossRef]

13. Prakash, K.S.; Rao, C.H. Study on compressive strength of quarry dust as fine aggregate in concrete. Adv. Civ. Eng. 2016, 2016, 1742769. [CrossRef]

14. Aishwaryalakshmi, V.; Kumar, N.; Prathap, M.G.; Haribabu, S. Experimental study on strength of concrete by partial replacement of fine aggregates with quarry dust. Int. J. Civ. Eng Tech. (IJCIET) 2017, 8, 12-17.

15. Jagadeesh, P.; Kumar, P.S.; Prakash, S.S.V. Influence of quarry dust on compressive strength of concrete. Indian J. Sci. Tech. 2016, 9, 93663. [CrossRef]

16. Lim, S.K.; Tan, C.S.; Li, B.; Ling, T.; Hossain, M.U.; Poon, C.S. Utilizing high volumes quarry wastes in the production of lightweight foamed concrete. Constr. Build. Mater. 2017, 151, 441-448. [CrossRef] 
17. Kankam, C.K.; Meisuh, B.K.; Sossou, G.; Buabin, T.K. Stress-strain characteristics of concrete containing quarry rock dust as partial replacement of sand. Case Stud. Constr. Mater. 2017, 7, 66-72. [CrossRef]

18. Thomas, J.; Harilal, B. Properties of cold bonded quarry dust coarse aggregates and its use in concrete. Cem. Concr. Compos. 2016, 62, 67-75. [CrossRef]

19. André, A.; De Brito, J.; Rosa, A.; Pedro, D. Durability performance of concrete incorporating coarse aggregates from marble industry waste. J. Cleaner Product. 2014, 65, 389-396. [CrossRef]

20. Mansor, A.M.; Elshab, A.A.; Borg, R.P.; Hamed, A.M. Effect of Marble Waste sand Waste on the properties of Self Compacting Concrete. In Proceedings of the SynerCrete'18: Interdisciplinary Approaches for Cement-Based Materials and Structural Concrete: Synergizing Expertise and Bridging Scales of Space and Time. (SynerCrete'18), Funchal, Portugal, 24-26 October 2018. Final Conference of COST Action TU1404. [CrossRef]

21. Sabău, M.; Vargas, J. Use of e-plastic waste in concrete as a partial replacement of coarse mineral aggregate. Comput. Concr. 2018, 21,377-384.

22. Siddique, R.; Khatib, J.; Kaur, I. Use of recycled plastic in concrete: A review. Waste Manag. 2008, 28, 1835-1852. [CrossRef]

23. Hameed, A.M.; Ahmed, B.A.F. Employment the plastic waste to produce the lightweight concrete. Energy Procedia 2019, 157, 30-38. [CrossRef]

24. Borg, R.P.; Baldacchino, O.; Ferrara, L. Early age performance and mechanical characteristics of PET fibre reinforced concrete. Constr. Build. Mater. 2016, 108, 29-47. [CrossRef]

25. Kepniak, M.; Woyciechowski, P.; Franus, W. Chemical and physical properties of limestone powder as a potential microfiller of polymer composites. Arch. Civ. Eng. 2017, 63, 67-78. [CrossRef]

26. Kepniak, M.; Woyciechowski, P.; Lukowaki, P.; Kuziak, J.; Kobylka, R. The Durability of Concrete Modified by Waste Limestone Powder in the Chemically Aggressive Environment. Materials 2019, 12, 1693. [CrossRef] [PubMed]

27. Ramesan, A.; Babu, S.S.; Lal, A. Durability and Bonding Characteristics of Plastic Aggregate Concrete. IOSR J. Mech. Civ. Eng. 2015, 12, 30-37.

28. Visweswara, S.D.; Sunil kumar, K.; Vimala, A. Experimental Investigation on Mechanical and Durability Properties of Concrete with Plastic Waste. Int. J. Eng. Technol. 2018, 7, 32-36.

29. Nwaubani, S.O.; Parsons, L.A. Properties, durability and microstructure of concrete incorporating waste electrical and electronic plastics as partial replacement for aggregates in concrete. Case Stud. Constr. Mater. 2021, 15, e00731. [CrossRef]

30. Rahimi, A.; García, J.M. Chemical recycling of waste plastics for new materials production. Nat. Rev. Chem. 2017, 1, 0046. [CrossRef]

31. Ferrándiz-Mas, V.; Sarabia, L.A.; Ortiz, M.C.; Cheeseman, C.R.; García-Alcocel, E. Design of bespoke lightweight cement mortars containing waste expanded polystyrene by experimental statistical methods. Mater. Des. 2016, 89, 901-912. [CrossRef]

32. Hussien, R.M.; Abd El-Hafez, L.M.; Mohamed, R.A.S.; Faried, A.S.; Fahmy, N.G. Influence of nano waste materials on the mechanical properties, microstructure, and corrosion resistance of self-compacted concrete. Case Stud. Constr. Mater. 2022, 16, e00859. [CrossRef]

33. Srividya, T.; Kannan Rajkumar, P.R.; Sivasakthi, M.; Sujitha, A.; Jeyalakshmi, R. A state-of-the-art on development of geopolymer concrete and its field applications. Case Stud. Constr. Mater. 2022, 16, e00812.

34. Zeyad, A.M.; Magbool, H.M.; Tayeh, B.A.; Garcez de Azevedo, A.R.; Abutaleb, A.; Hussain, Q. Production of geopolymer concrete by utilizing volcanic pumice dust. Case Stud. Constr. Mater. 2022, 16, e00802. [CrossRef] 